\title{
PENGARUH LUAS LAHAN TERHADAP PENERIMAAN, BIAYA PRODUKSI, DAN PENDAPATAN USAHATANI PADI SAWAH DI DESA TOINASA KECAMATAN PAMONA BARAT
}

\author{
The Effect of Land Size on Revenue, Cost Production, and Income \\ of Rice Field Farming at Toinasa Village West Pamona District \\ Marianne Reynelda Mamondol ${ }^{1)}$ \\ Ferdinan Sabe ${ }^{2)}$ \\ ${ }^{1,2}$ Fakultas Pertanian Universitas Kristen Tentena \\ Jln. Torulemba No. 21 Tentena, Poso, Sulawesi Tengah \\ e-mail : mariannemamondol@gmail.com
}

\begin{abstract}
Abstrak
Penelitian ini bertujuan untuk mengetahui pengaruh luas lahan terhadap penerimaan, biaya produksi, dan pendapatan usahatani padi sawah di Desa Toinasa Kecamatan Pamona Barat. Pengumpulan data dilakukan melalui survey dengan pengisian kuisioner dan wawancara dengan responden penelitian. Sampel responden sebanyak 16 orang ditentukan melalui teknik sampling berstrata. Data yang diperoleh dianalisis dengan menggunakan analisis pendapatan dan regresi linear sederhana. Hasil penelitian menunjukkan bahwa penerimaan rata-rata petani dengan luas lahan < 0,5 ha ialah sebesar $R p$ 4.053.160/MT, biaya produksi rata-rata sebesar $R p$ 3.302.599,33/MT, dan pendapatan rata-rata sebesar $R p$ 750.560,67/MT. Petani dengan luas lahan antara 0,5 - 1 ha memiliki penerimaan rata-rata sebesar $R p$ 11.892.624/MT, biaya produksi ratarata sebesar $R p$ 7.579.606,60/MT, dan pendapatan rata-rata sebesar $R p$ 4.313.017,40/MT. Penerimaan rata-rata petani dengan luas lahan > 1 ha ialah sebesar Rp 25.803.240/MT, biaya produksi rata-rata sebesar $R p$ 14.831.693,67/MT dan pendapatan rata-rata sebesar $R p$ 10.971.546,33/MT. Terdapat hubungan yang positif dan signifikan antara luas lahan dengan penerimaan, biaya produksi, dan pendapatan usahatani. Peningkatan luas lahan menyebabkan kenaikan penerimaan, biaya produksi, dan pendapatan. Walaupun demikian, peningkatan luas lahan menyebabkan kenaikan biaya produksi yang lebih besar dibandingkan kenaikan pendapatan, mengindikasikan adanya inefisiensi dalam kegiatan usahatani.
\end{abstract}

Kata Kunci : luas lahan, penerimaan, biaya produksi, pendapatan, usahatani padi sawah

\begin{abstract}
The purpose of this research is to find out the effect of land size on revenue, cost production, and income of rice field farming at Toinasa Village West Pamona District. Data collection is conducted through survey, which includes questionnaire and interviewing the respondents. 16 respondents as samples are determined with stratified sampling technique. Data is then analyzed applying income analysis and simple linear regression analysis. Study results show that the average revenue offarmers with land size less than $0.5 \mathrm{ha}$ is $R p$ 4,053,160/harvest, average cost production is $R p$ 3,302,599.33/harvest, and average income is $R p$ 750,560.77/harvest. Farmers with land size between 0.5 and 1 ha have average revenue $R p \quad 11,892,624 /$ harvest, average cost production $R p$ 7,579,606.60/harvest, and average income Rp 4,313,017.40/harvest. Farmers with land size more than 1 ha have average revenue $R p$ 25,803,240/harvest, average cost production $R p$ 14,831,693.67/harvest, and average income $R p$ 10,971,546.33/harvest. There is a positive and significant relationship between land size and revenue, cost, and income. The increasing of land size gives incline in revenue, cost, and income. However, the increasing of land size promotes cost production higher than income, indicates an inefficiency in farming activities.
\end{abstract}

Keywords : land size, revenue, cost production, income, rice field farming 


\section{PENDAHULUAN}

Bagi perekonomian nasional, sektor pertanian berperan sebagai penghasil bahan pangan, penghasil bahan baku bagi sektor industri, sumber devisa, sumber investasi, dan sumber pemasok tenaga kerja. Padi sawah merupakan tanaman pangan yang umumnya diusahakan oleh banyak rumah tangga petani di pedesaan. Beras merupakan komoditi yang sangat penting karena fungsinya sebagai bahan makanan pokok dan sumber kalori bagi sebagian besar penduduk Indonesia. Permintaan terhadap beras secara tidak langsung juga mempengaruhi permintaan terhadap bahan pangan lainnya (Mahananto $d k k, 2009)$.

Permasalahan yang ditemui di lapangan khususnya pada usaha pertanian padi sawah ialah berbagai masalah teknis, sebagai contoh usahatani padi sering mengalami kerugian dalam hal pengelolaan usaha akibat dari petani tidak pernah melakukan pencatatan secara terperinci mengenai usahatani yang dilakukannya. Akibatnya petani lebih cenderung mengalihkan lahan pertanian padi sawah menjadi lahan perkebunan dengan alasan mengelola usaha tanaman padi membutuhkan lebih banyak biaya produksi.

Desa Toinasa di Kecamatan Pamona Barat merupakan salah satu desa yang rata-rata penduduknya memiliki mata pencaharian di bidang pertanian, khususnya sebagai petani padi sawah. Ini berarti bahwa pemenuhan kebutuhan keluarga sebagian besar dilakukan dari bertani padi sawah. Usahatani padi sawah varietas Superwin di desa Toinasa awalnya hanya dapat melakukan panen satu kali dalam setahun. Seiring oleh perkembangan teknologi, alat-alat pertanian sudah mulai digunakan para petani di desa ini sehingga masa panen dapat dilakukan dua kali dalam setahun sampai sekarang ini. Dilihat dari potensi lahan, padi sawah di desa Toinasa diusahakan pada lahan yang cukup luas. Setiap kepala keluarga rata-rata memiliki lahan produktif pertanian padi sawah dengan luas 0,5 hingga 1 ha.

Petani seringkali membandingkan antara hasil yang diharapkan akan diterima sewaktu panen dengan biaya yang harus dikeluarkannya. Hasil ekonomi yang diperoleh petani melalui produksi saat panen merupakan penerimaan, sedangkan biaya yang dikeluarkan disebut biaya produksi. Selisih antara penerimaan dan biaya produksi merupakan pendapatan bersih petani (Suratiyah, 2008). Pada umumnya diasumsikan bahwa semakin besar luas lahan maka tingkat pendapatan yang diperoleh akan semakin besar. Akan tetapi penggunaan lahan yang semakin besar memiliki konsekuensi penggunaan faktor-faktor produksi lainnya seperti benih, pupuk, pestisida, dan uang tunai dalam jumlah yang lebih besar pula (Prayoga, 2010). Pemanfaatan faktor-faktor produksi secara maksimal dapat membuat petani mencapai tingkat pendapatan yang maksimal pada setiap luas lahan yang digunakan untuk berusahatani (Dewi $d k k, 2012$ ).

Salah satu penyebab kegagalan petani dalam melaksanakan usahatani ialah rendahnya produktivitas akibat inefisiensi penggunaan faktor-faktor produksi. Hal ini terjadi pada usahatani berskala kecil, di mana sempitnya lahan usahatani yang dikelola menyebabkan penggunaan dan harga sarana produksi per satuan luas menjadi lebih besar (Isyanto, 2012). Produktivitas adalah tingkatan efisiensi dalam memproduksi ouput dari suatu proses produksi (Ramadhani, 2011), di mana efisiensi itu sendiri tidak dapat dipisahkan dari skala usaha (Nazam $d k k$, 2011). Hasil penelitian Kusnadi et al (2011) menunjukkan bahwa semakin luas lahan sawah yang dikelola maka tingkat efisiensi akan semakin besar, di mana biaya produksi per satuan luas lahan akan semakin kecil sehingga meningkatkan pendapatan yang diperoleh petani dari usahatani yang dikerjakannya.

Di Indonesia, definisi petani kecil lebih sering mengacu pada luas lahan usahatani. Sayogyo (1977) dalam Susilowati dan Maulana (2012) mengelompokkan petani ke dalam tiga kategori yaitu petani skala kecil dengan luas lahan usahatani $<0,5$ ha, petani skala menengah dengan luas lahan usahatani $0,5-1$ ha, dan petani skala besar denga luas lahan usahatani $>1$ ha.

Menurut pemahaman umum, usahatani pada lahan sempit kurang efisien sehingga usahatani pada lahan berukuran besar lebih disukai. Namun beberapa hasil kajian menyimpulkan bahwa usahatani skala kecil pada dasarnya tidak lebih buruk dibandingkan usahatani skala besar, paling tidak memiliki efisiensi produksi yang sama (Peterson, 1997 dalam Susilowati dan Maulana, 2012). 
Bahkan menurut Rosset (1999) dalam Susilowati dan Maulana (2012) terdapat bukti yang menunjukkan hubungan terbalik antara luas lahan dan produktivitas. Karena itu Sudaryanto et al (2009) menyatakan bahwa ukuran usahatani bukan merupakan masalah pada tataran implementasi. Permasalahan sempitnya penguasaan lahan usahatani lebih mengarah pada aspek pemenuhan kebutuhan rumah tangga dari hasil usahatani. Meskipun dilakukan secara intensif, usahatani lahan sempit sulit untuk memenuhi kebutuhan rumah tangga petani sehingga diperlukan tambahan pendapatan dari sumber-sumber lain.

Adapun tujuan penelitian ini ialah untuk menganalisis pengaruh luas lahan terhadap penerimaan, biaya produksi, dan pendapatan usahatani padi sawah pada petani di Desa Toinasa Kecamatan Pamona Barat.

\section{METODE PENELITIAN}

Penelitian ini dilaksanakan di Desa Toinasa Kecamatan Pamona Barat Kabupaten Poso pada bulan Agustus hingga November 2013. Pengumpulan data dilakukan dengan menggunakan metode survey. Survey dilakukan dengan mengadakan observasi berupa tindakan peninjauan langsung di lapangan, wawancara atau proses dialog antara peneliti dengan beberapa pihak terkait, dan dokumentasi berupa pengambilan dokumen dalam bentuk catatan-catatan, arsip, serta laporan-laporan mengenai usahatani padi sawah Superwin yang dilaksanakan petani.

Populasi dalam penelitian adalah 64 petani padi sawah yang mengolah lahan milik sendiri di Desa Toinasa Kecamatan Pamona Barat. Pada penelitian ini penentuan sampel dilakukan secara stratifikasi (stratified sampling) yakni petani yang memiliki luas lahan < 0,5 ha, 0,5 s/d 1 ha, dan > 1 ha. Sampel penelitian ialah sebanyak 16 petani, yakni 3 petani dengan luas lahan <0,5 ha, 10 petani dengan luas lahan $0,5 \mathrm{~s} / \mathrm{d} 1 \mathrm{ha}$, dan 3 petani dengan luas lahan $>1$ ha. Penentuan jumlah sampel per strata dilakukan secara proporsional.

Data yang dikumpulkan meliputi data primer dengan sumber data ialah petani responden. Data primer yang dikumpulkan ialah : (a) Identitas responden, (b) Penerimaan petani dari produksi padi sawah dan dedak, (c) Harga jual padi sawah dan dedak, (d) Biaya pajak lahan, (e) Peralatan usahatani yang digunakan (jenis dan jumlah alat, tahun pembelian, harga pembelian), (f) Penggunaan pupuk dan pestisida (kebutuhan dan biaya pembelian), (g) Penggunaan tenaga kerja (asal tenaga kerja, jumlah dan biaya tenaga kerja untuk berbagai kegiatan, dan (h) Biaya pembelian sak, sewa peralatan, angkutan gabah, serta sewa huller. Penerimaan dan biaya-biaya yang dikeluarkan dihitung dalam 1 musim tanam (MT).

Variabel-variabel yang digunakan dalam penelitian ini ialah : (a) Penerimaan total, yaitu penerimaan petani dari penjualan beras dan dedak (Rp / MT), (b) Penerimaan petani dari penjualan beras, yaitu produksi beras per MT dikalikan dengan harga jual beras per unit (Rp/MT), (c) Penerimaan petani dari penjualan dedak, yaitu produksi dedak per MT dikalikan dengan harga jual dedak per unit (Rp / MT), (d) Produksi beras, yaitu kuantitas beras yang dihasilkan pada saat panen (kg), (e) Harga jual beras, yaitu harga penjualan beras per unit dari petani kepada pedagang $(\mathrm{Rp} / \mathrm{kg}$ ), (e) Produksi dedak, yaitu kuantitas dedak yang dihasilkan pada saat panen (sak), (f) Harga jual dedak, yaitu harga penjualan dedak per unit dari petani kepada pedagang (Rp / sak), (g) Biaya produksi, yaitu jumlah seluruh biaya yang dikeluarkan oleh petani untuk usahatani padi sawah selama satu musim tanam (Rp / MT), (h) Pendapatan, yaitu selisih antara penerimaan total dengan biaya produksi ( $\mathrm{Rp} /$ MT), dan (i) Luas lahan, yaitu besarnya lahan yang diusahakan oleh petani untuk budidaya tanaman padi sawah varietas Superwin (ha).

Teknik analisis data yang digunakan dalam penelitian ini ialah :

1) Analisis pendapatan dengan rumus :

$$
\pi=\mathrm{TR}-\mathrm{TC}
$$

(Bangun, 2007)

di mana :

$$
\begin{aligned}
& \pi=\mathrm{P} \cdot \mathrm{Q}-\mathrm{TC} \\
& \pi=\left(\mathrm{P}_{1} \cdot \mathrm{Q}_{1}+\mathrm{P}_{2} \cdot \mathrm{Q}_{2}\right)-\mathrm{TC} \\
& \text { Keterangan }: \\
& \pi=\text { Pendapatan }(\mathrm{Rp} / \mathrm{MT}) \\
& \mathrm{TR}=\text { Penerimaan total }(\mathrm{Rp} / \mathrm{MT}) \\
& \mathrm{TC}=\text { Biaya produksi }(\mathrm{Rp} / \mathrm{MT}) \\
& \mathrm{P}_{1}=\text { Harga jual beras }(\mathrm{Rp} / \mathrm{kg}) \\
& \mathrm{Q}_{1}=\text { Produksi beras }(\mathrm{kg}) \\
& \mathrm{P}_{2}=\text { Harga jual dedak }(\mathrm{Rp} / \mathrm{sak}) \\
& \mathrm{Q}_{2}=\text { Produksi dedak }(\mathrm{sak})
\end{aligned}
$$

2) Analisis regresi linear sederhana dengan rumus : 


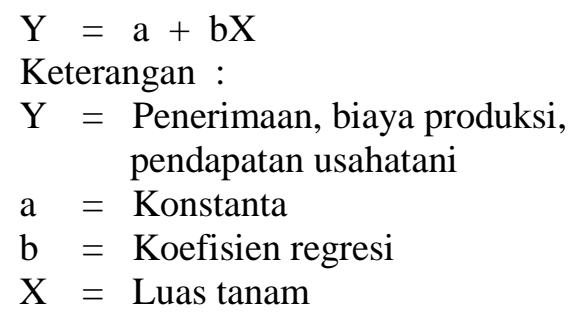

Uji keberartian koefisien regresi dilakukan dengan membandingkan $\mathrm{F}$ hitung dengan $\mathrm{F}$ tabel pada $\alpha=5 \%$. Koefisien regresi dinyatakan berarti apabila $\mathrm{F}$ hitung lebih besar daripada $\mathrm{F}$ tabel.

Uji linearitas koefisien regresi dilakukan dengan membandingkan $\mathrm{F}$ hitung dengan F tabel pada $\alpha=5 \%$. Koefisien regresi dinyatakan linear apabila $\mathrm{F}$ hitung lebih kecil daripada $\mathrm{F}$ tabel.

Uji korelasi untuk menentukan besar dan arah hubungan antara variabel bebas dan terikat dilakukan dengan menggunakan rumus korelasi Pearson Product Moment :

$$
r_{x y}=\frac{n \sum x_{i} y_{i}-\left(\sum x_{i}\right)\left(\sum y_{i}\right)}{\sqrt{\left(n \sum x_{i}^{2}-\left(\sum x_{i}\right)^{2}\right)\left(n \sum y_{i}^{2}-\left(\sum y_{i}\right)^{2}\right)}}
$$

(Somantri dan Muhidin, 2006)
Nilai koefisien korelasi dinyatakan signifikan apabila $r$ hitung lebih besar daripada $\mathrm{r}$ tabel pada $\alpha=5 \%$.

Koefisien determinasi (R) ditentukan dengan rumus :

$\mathrm{R}=\mathrm{r}^{2} \times 100 \%$

Nilai R menunjukkan persentase pengaruh variabel bebas terhadap variabel terikat.

\section{HASIL DAN PEMBAHASAN \\ Penerimaan}

Penerimaan petani berasal dari penjualan beras dan dedak. Hasil penelitian menunjukan bahwa 1 kwintal gabah menghasilkan $53,2 \mathrm{~kg}$ beras dengan harga jual sebesar Rp $6.200 / \mathrm{kg}$, sedangkan harga dedak ialah $\mathrm{Rp} 60.000$ / sak. Pada dasarnya hasil yang diperoleh tidak terjual semua melainkan sebagian disimpan untuk kebutuhan konsumsi petani dan keluarga. Tetapi dalam penelitian ini untuk menghitung besarnya total penerimaan maka produksi beras dan gabah baik yang terjual maupun dikonsumsi dinilai dengan uang.

Tabel 1. Penerimaan Petani dengan Luas Lahan $<0,5$ ha

\begin{tabular}{cccrr} 
Responden & Luas Lahan & $\begin{array}{c}\text { Penerimaan dari } \\
\text { Beras } \\
\text { (Rp/MT) }\end{array}$ & $\begin{array}{c}\text { Penerimaan dari } \\
\text { Dedak } \\
\text { (Rp/MT) }\end{array}$ & $\begin{array}{c}\text { Penerimaan } \\
\text { Total } \\
\text { (Rp/MT) }\end{array}$ \\
\hline A & 0,25 & 3.463 .320 & 240.000 & 3.703 .320 \\
B & 0,30 & 4.123000 & 300.000 & 4.423 .000 \\
C & 0,40 & 3.793 .160 & 240.000 & 4.033 .160 \\
\hline
\end{tabular}

Tabel 2. Penerimaan Petani dengan Luas Lahan 0,5 - 1 ha

\begin{tabular}{ccrrr} 
Responden & Luas Lahan & $\begin{array}{c}\text { Penerimaan dari } \\
\text { Beras } \\
\text { (Rp/MT) }\end{array}$ & $\begin{array}{c}\text { Penerimaan dari } \\
\text { Dedak } \\
\text { (Rp/MT) }\end{array}$ & $\begin{array}{c}\text { Penerimaan } \\
\text { Total } \\
\text { (Rp/MT) }\end{array}$ \\
\hline D & (ha) & 5.277 .440 & 360.000 & 5.637 .440 \\
E & 0,5 & 7.421 .400 & 480.000 & 7.901 .400 \\
F & 0,5 & 6.596 .800 & 480.000 & 7.076 .800 \\
G & 0,6 & 11.874 .240 & 900.000 & 12.774 .240 \\
H & 0,8 & 14.842 .800 & 1.020 .000 & 15.862 .800 \\
I & 1,0 & 11.874 .240 & 960.000 & 12.834 .240 \\
J & 1,0 & 17.811 .360 & 1.320 .000 & 19.131 .360 \\
K & 1,0 & 10.389 .960 & 720.000 & 11.109 .960 \\
L & 1,0 & 14.842 .800 & 960.000 & 15.802 .800 \\
M & 1,0 & 9.895 .200 & & \\
\end{tabular}


Tabel 3. Penerimaan Petani dengan Luas Lahan $>1$ ha

\begin{tabular}{cccrr} 
Responden & Luas Lahan & $\begin{array}{c}\text { Penerimaan dari } \\
\text { Beras } \\
(\mathrm{Rp} / \mathrm{MT})\end{array}$ & $\begin{array}{c}\text { Penerimaan dari } \\
\text { Dedak } \\
(\mathrm{Rp} / \mathrm{MT})\end{array}$ & $\begin{array}{c}\text { Penerimaan } \\
\text { Total } \\
(\mathrm{Rp} / \mathrm{MT})\end{array}$ \\
\hline $\mathrm{N}$ & 1,3 & 22.264 .200 & 1.500 .000 & 23.764 .200 \\
$\mathrm{O}$ & 2,0 & 23.748 .480 & 1.560 .000 & 25.308 .480 \\
$\mathrm{P}$ & 2,0 & 26.717 .040 & 1.620 .000 & 28.337 .040 \\
\hline
\end{tabular}

Hubungan antara luas lahan (X) dan penerimaan (Y) digambarkan dalam persamaan regresi linear sederhana pada Gambar 1. Hasil analisis regresi linear sederhana menunjukkan bahwa setiap kenaikan 1 ha luas lahan akan menyebabkan kenaikan penerimaan sebesar $\mathrm{Rp}$ 14.173.902,42/MT. Koefisien korelasi sebesar 0,95 memperlihatkan hubungan yang positif dan signifikan antara luas lahan dengan penerimaan. Nilai koefisien determinasi (R) sebesar 90,25\% menunjukkan bahwa besar pengaruh luas lahan terhadap jumlah penerimaan usahatani padi sawah ialah sebesar $90,25 \%$.

Besarnya penerimaan ditentukan oleh dua komponen, yaitu harga jual per unit produk dan produksi total. Karena harga jual sama untuk semua kategori luas lahan maka faktor yang mempengaruhi penerimaan ialah produksi. Semakin besar luas lahan yang diusahakan petani maka tingkat produksi yang diperoleh juga semakin besar sehingga meningkatkan jumlah penerimaan usahatani.

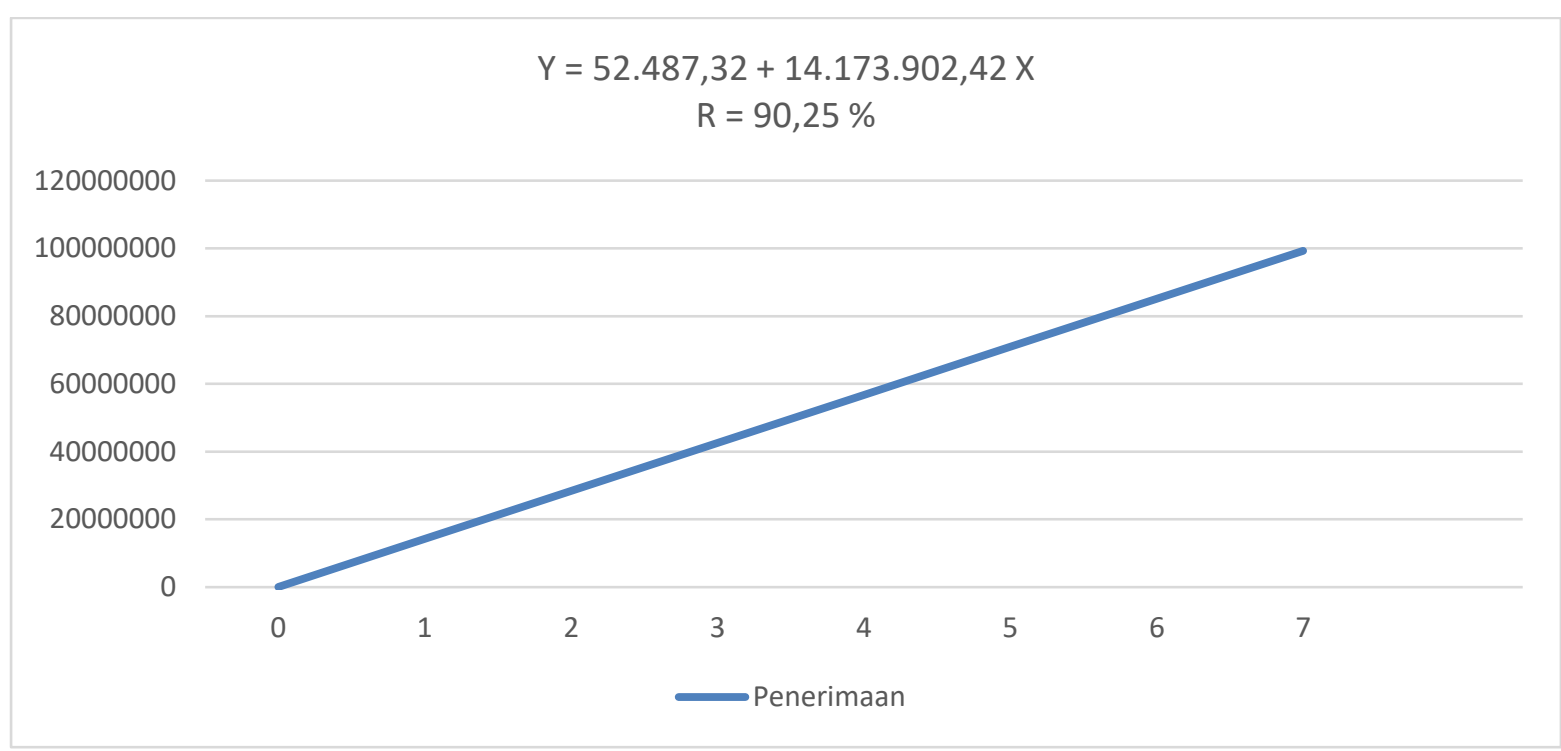

Gambar 1. Hubungan Luas Lahan dengan Penerimaan

\section{Biaya Produksi}

Biaya produksi usahatani padi sawah pada petani dengan luas lahan $<0,5$ ha, $0,5-1$ ha, dan $>1$ ha diperlihatkan dalam Tabel 4, 5, dan 6 sedangkan hubungan antara luas lahan $(\mathrm{X})$ dan biaya produksi (Y) digambarkan dalam persamaan regresi linear sederhana pada Gambar 2. Hasil analisis regresi linear sederhana menunjukkan bahwa setiap kenaikan 1 ha luas lahan akan menyebabkan kenaikan biaya produksi sebesar $\mathrm{Rp}$ 7.733.109,97/MT. Koefisien korelasi sebesar 0,98 memperlihatkan hubungan yang positif dan signifikan antara luas lahan dengan biaya produksi. Nilai koefisien determinasi (R) sebesar 96,04\% menunjukkan bahwa besar pengaruh luas lahan terhadap biaya produksi usahatani padi sawah ialah sebesar 96,04\%.

Biaya produksi usahatani padi sawah meliputi biaya tetap berupa pembayaran pajak 
lahan, penyusutan alat, dan upah tenaga kerja keluarga, serta biaya variabel berupa biaya pembelian sarana produksi (bibit, pupuk, pestisida), upah tenaga kerja luar keluarga, dan biaya sewa peralatan (traktor untuk pengolahan tanah dan penggilingan / huller).
Peningkatan luas lahan menyebabkan kebutuhan biaya produksi yang semakin besar, karena petani membutuhkan sarana produksi yang lebih banyak jumlahnya dan pembayaran sewa peralatan yang semakin besar pula.

Tabel 4. Biaya Produksi Petani dengan Luas Lahan $<0,5$ ha

\begin{tabular}{cccr}
\hline No. & Responden & $\begin{array}{c}\text { Luas Lahan } \\
\text { (ha) }\end{array}$ & $\begin{array}{c}\text { Biaya Produksi } \\
\text { (Rp/MT) }\end{array}$ \\
\hline 1 & A & 0,25 & 2.479 .282 \\
2 & B & 0,30 & 3.494 .750 \\
3 & C & 0,40 & 3.933 .766 \\
\hline
\end{tabular}

Tabel 5. Biaya Produksi Petani dengan Luas Lahan 0,5 - 1 ha

\begin{tabular}{cccr}
\hline No. & Responden & $\begin{array}{c}\text { Luas Lahan } \\
\text { (ha) }\end{array}$ & $\begin{array}{c}\text { Biaya Produksi } \\
\text { (Rp/MT) }\end{array}$ \\
\hline 1 & $\mathrm{D}$ & 0,5 & 3.903 .669 \\
2 & $\mathrm{E}$ & 0,5 & 5.792 .090 \\
3 & $\mathrm{~F}$ & 0,6 & 4.025 .130 \\
4 & $\mathrm{G}$ & 0,8 & 8.304 .224 \\
5 & $\mathrm{H}$ & 1,0 & 8.674 .730 \\
6 & $\mathrm{I}$ & 1,0 & 8.566 .374 \\
7 & $\mathrm{~J}$ & 1,0 & 1.100 .778 \\
8 & $\mathrm{~K}$ & 1,0 & 8.309 .946 \\
9 & $\mathrm{~L}$ & 1,0 & 8.861 .730 \\
10 & $\mathrm{M}$ & 1,0 & 8.257 .395 \\
\hline
\end{tabular}

Tabel 6. Biaya Produksi Petani dengan Luas Lahan $>1$ ha

\begin{tabular}{cccc}
\hline No. & Responden & $\begin{array}{c}\text { Luas Lahan } \\
\text { (ha) }\end{array}$ & $\begin{array}{c}\text { Biaya Produksi } \\
\text { (Rp/MT) }\end{array}$ \\
\hline 1 & $\mathrm{~N}$ & 1,3 & 12.994 .820 \\
2 & $\mathrm{O}$ & 2,0 & 15.187 .940 \\
3 & $\mathrm{P}$ & 2,0 & 16.312 .321 \\
\hline
\end{tabular}

$$
\begin{gathered}
Y=1.056 .494,096+7.733 .109,97 X \\
R=96,04 \%
\end{gathered}
$$

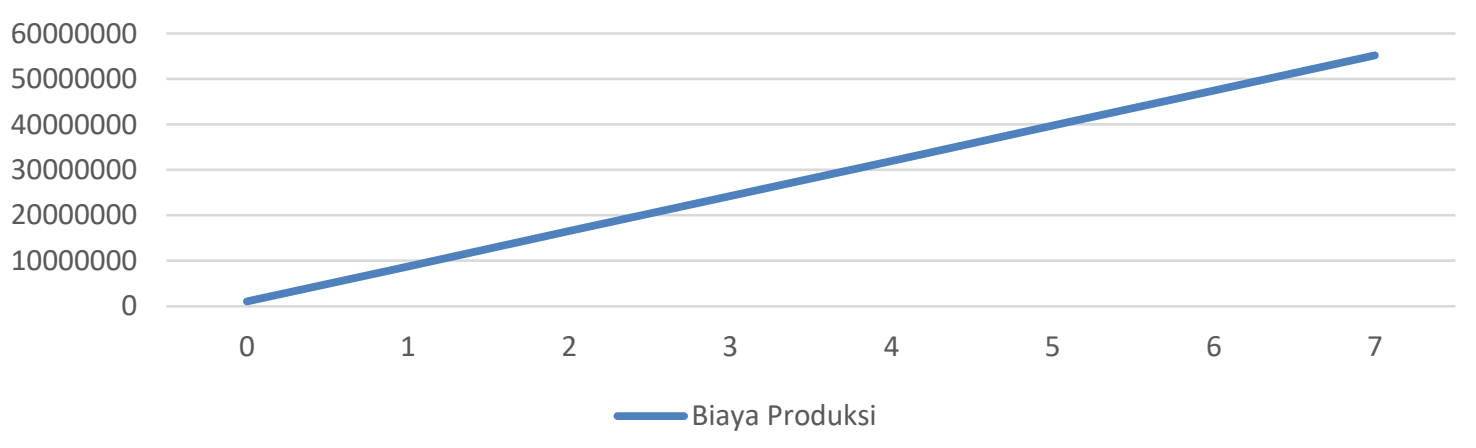

Gambar 2. Hubungan Luas Lahan dengan Biaya Produksi 


\section{Pendapatan}

Pendapatan usahatani padi sawah pada petani dengan luas lahan $<0,5$ ha, $0,5-1$ ha, dan $>1$ ha diperlihatkan dalam Tabel 7, 8, dan 9, sedangkan hubungan antara luas lahan $(\mathrm{X})$ dan pendapatan (Y) digambarkan dalam persamaan regresi linear sederhana pada Gambar 3. Hasil analisis regresi linear sederhana menunjukkan bahwa setiap kenaikan 1 ha luas lahan akan menyebabkan kenaikan pendapatan sebesar Rp 6.440792,45/MT. Koefisien korelasi sebesar 0,89 memperlihatkan hubungan yang positif dan signifikan antara luas lahan dengan biaya produksi. Nilai koefisien determinasi (R) sebesar 79,21\% menunjukkan bahwa besar pengaruh luas lahan terhadap biaya produksi usahatani padi sawah ialah sebesar 79,21\%.

Pendapatan merupakan selisih antara penerimaan dengan biaya produksi. Semakin besar luas lahan berarti pendapatan petani akan semakin besar, sehingga kemampuan petani untuk memenuhi kebutuhan rumah tangga dan keluarganya juga dapat ditingkatkan. Selain memenuhi kebutuhan keluarga, pendapatan usahatani juga digunakan petani sebagai sumber permodalan usahatani pada musim tanam berikutnya.

Tabel 7. Pendapatan Petani dengan Luas Lahan $<0,5$ ha

\begin{tabular}{cccrr}
\hline Responden & $\begin{array}{c}\text { Luas Lahan } \\
\text { (ha) }\end{array}$ & $\begin{array}{c}\text { Penerimaan } \\
(\mathrm{Rp} / \mathrm{MT})\end{array}$ & $\begin{array}{c}\text { Biaya } \\
\text { Produksi } \\
(\mathrm{Rp} / \mathrm{MT})\end{array}$ & $\begin{array}{c}\text { Pendapatan } \\
(\mathrm{Rp} / \mathrm{MT})\end{array}$ \\
\hline A & 0,25 & 3.703 .320 & 2.479 .282 & 1.224 .038 \\
B & 0,30 & 4.423 .000 & 3.494 .750 & 928.250 \\
C & 0,40 & 4.033 .160 & 3.933 .766 & 99.394 \\
\hline Rata-rata & & 4.053 .160 & $3.302 .599,33$ & $750.560,67$ \\
\hline
\end{tabular}

Tabel 8. Pendapatan Petani dengan Luas Lahan 0,5 - 1 ha

\begin{tabular}{cccrr}
\hline Responden & $\begin{array}{c}\text { Luas Lahan } \\
(\text { ha })\end{array}$ & $\begin{array}{c}\text { Penerimaan } \\
(\mathrm{Rp} / \mathrm{MT})\end{array}$ & $\begin{array}{c}\text { Biaya } \\
\text { Produksi } \\
(\mathrm{Rp} / \mathrm{MT})\end{array}$ & $\begin{array}{c}\text { Pendapatan } \\
(\mathrm{Rp} / \mathrm{MT})\end{array}$ \\
\hline D & 0,5 & 5.637 .440 & 3.903 .669 & 1.733 .771 \\
E & 0,5 & 7.901 .400 & 5.792 .090 & 2.109 .310 \\
F & 0,6 & 7.076 .800 & 4.025 .130 & 3.051 .670 \\
G & 0,8 & 12.774 .240 & 8.304 .224 & 4.470 .016 \\
H & 1,0 & 15.862 .800 & 8.674 .730 & 7.188 .070 \\
I & 1,0 & 12.834 .240 & 8.566 .374 & 4.267 .866 \\
J & 1,0 & 19.131 .360 & 11.100 .778 & 8.030 .582 \\
K & 1,0 & 11.109 .960 & 8.309 .946 & 2.800 .014 \\
L & 1,0 & 15.802 .800 & 8.861 .730 & 6.941 .070 \\
M & 1,0 & 10.795 .200 & 8.257 .395 & 2.537 .805 \\
Rata-rata & & 11.892 .624 & $7.579 .606,6$ & $4.313 .017,4$ \\
\hline
\end{tabular}

Tabel 9. Pendapatan Petani dengan Luas Lahan > 1 ha

\begin{tabular}{cccrr}
\hline Responden & Luas Lahan & $\begin{array}{c}\text { Biaya } \\
\text { Penerimaan } \\
(\text { Rp/MT) }\end{array}$ & $\begin{array}{c}\text { Produksi } \\
\text { (Rp/MT) }\end{array}$ & \multicolumn{1}{c}{$\begin{array}{c}\text { Pendapatan } \\
\text { (Rp/MT) }\end{array}$} \\
\hline $\mathrm{N}$ & 1,3 & 23.764 .200 & 12.994 .820 & 10.769 .380 \\
$\mathrm{O}$ & 2,0 & 25.308 .480 & 15.187 .940 & 10.120 .540 \\
$\mathrm{P}$ & 2,0 & 28.337 .040 & 16.312 .321 & 12.024 .719 \\
\hline Rata-rata & & $25.803 .240,00$ & $14.831 .693,67$ & $10.971 .546,33$ \\
\hline
\end{tabular}




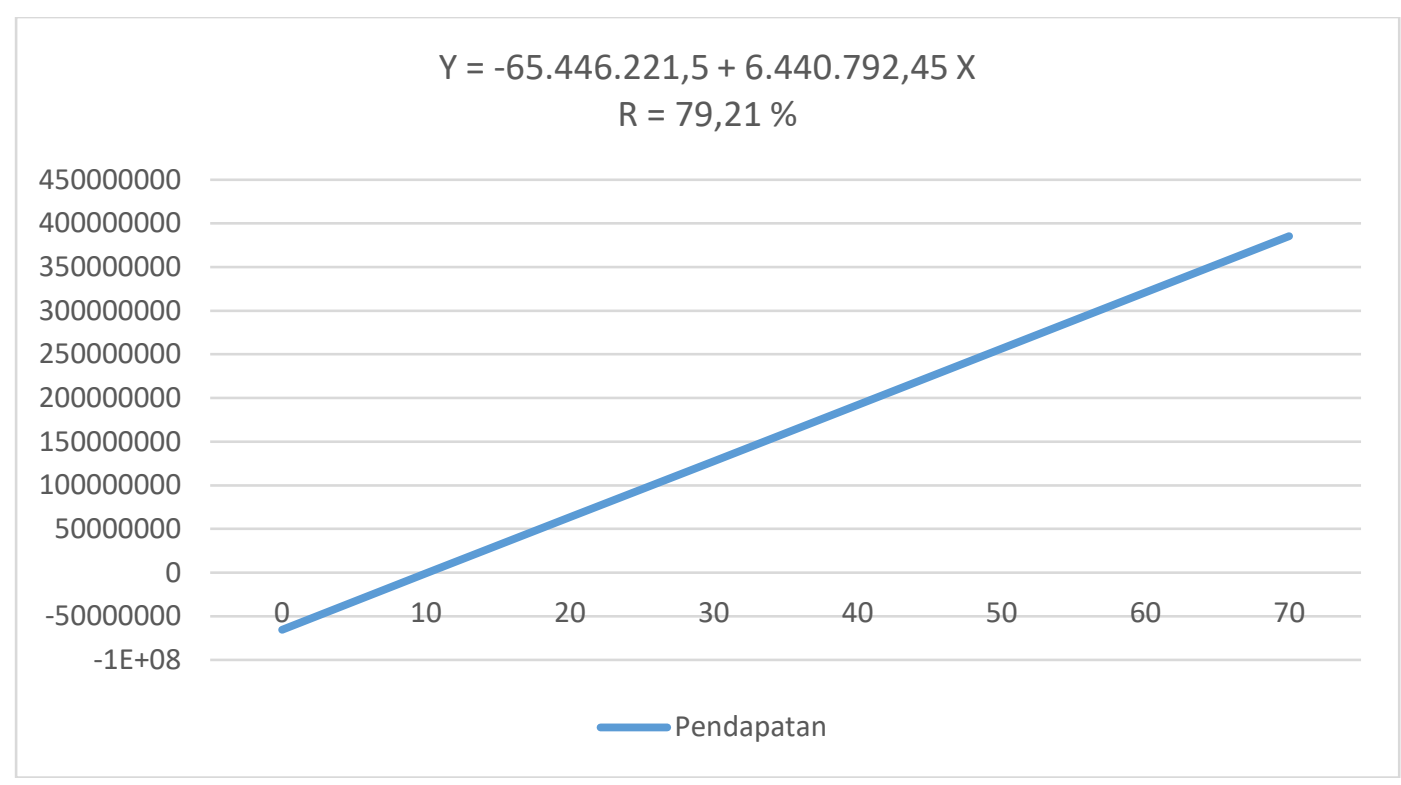

\section{Gambar 3. Hubungan Luas Lahan dengan Pendapatan}

Hasil analisis regresi linear sederhana memperlihatkan bahwa terdapat hubungan yang searah antara variabel luas lahan dengan variabel penerimaan, biaya produksi, dan penerimaan. Ini berarti bahwa kenaikan luas lahan menyebabkan kenaikan penerimaan, biaya produksi, dan pendapatan petani. Namun untuk melihat efisiensi penggunaan biaya produksi pada usahatani perlu diperhitungkan proporsi biaya produksi dan pendapatan terhadap penerimaan. Perhitungan tersebut diperlihatkan dalam Tabel 10.

Semakin besar luas lahan menyebabkan jumlah penerimaan usahatani semakin meningkat, tetapi konsekuensinya biaya yang dikeluarkan petani untuk operasi usahatani juga semakin besar. Peningkatan biaya produksi akan mempengaruhi jumlah pendapatan yang diterima oleh petani. Analisis regresi linear sederhana menunjukkan bahwa setiap kenaikan luas lahan sebesar 1 ha menyebabkan peningkatan biaya produksi sebesar Rp 7.733.109,97/MT, sementara kenaikan pendapatan hanya sebesar $\mathrm{Rp}$ $6.440 .792,45 / \mathrm{MT}$. Jadi peningkatan biaya produksi lebih besar dibandingkan dengan peningkatan pendapatan.

Perhitungan proporsi biaya produksi dan pendapatan terhadap penerimaan diperlihatkan pada tabel berikut.

Tabel 10. Proporsi Biaya Produksi dan Pendapatan terhadap Penerimaan pada Luas Lahan $<0,5$ ha

\begin{tabular}{ccrrr}
\hline \multicolumn{2}{c}{ Responden } & $\begin{array}{c}\text { Proporsi biaya produksi terhadap } \\
\text { peneriman }(\%)\end{array}$ & \multicolumn{2}{c}{$\begin{array}{c}\text { Proporsi pendapatan terhadap } \\
\text { penerimaan }(\%)\end{array}$} \\
\hline 1 & A & & 66,95 & 33,05 \\
2 & B & 79,01 & 20,99 \\
3 & C & 97,53 & 2,47 \\
& Rerata & 81,16 & 18,84 \\
\hline
\end{tabular}


Tabel 11. Proporsi Biaya Produksi dan Pendapatan terhadap Penerimaan pada Luas Lahan $0,5-1$ ha

\begin{tabular}{cccc}
\hline No. & Responden & $\begin{array}{c}\text { Proporsi biaya produksi terhadap } \\
\text { penerimaan }(\%) \\
(\%)\end{array}$ & $\begin{array}{c}\text { Proporsi pendapatan terhadap } \\
\text { penerimaan }(\%) \\
(\%)\end{array}$ \\
\hline 1 & D & 69,25 & 30,75 \\
2 & E & 73,30 & 26,70 \\
3 & F & 56,88 & 43,12 \\
4 & G & 65,00 & 35,00 \\
5 & H & 54,69 & 45,31 \\
6 & I & 66,75 & 33,25 \\
7 & J & 58,02 & 41,98 \\
8 & K & 74,80 & 25,20 \\
9 & L & 56,08 & 43,92 \\
10 & M & 76,49 & 23,51 \\
& Rerata & 65,13 & 34,87 \\
\hline
\end{tabular}

Tabel 12. Proporsi Biaya Produksi dan Pendapatan terhadap Penerimaan pada Luas Lahan $>1$ ha

\begin{tabular}{|c|c|c|c|}
\hline No. & Responden & $\begin{array}{c}\text { Proporsi biaya produksi terhadap } \\
\text { penerimaan } \\
(\%)\end{array}$ & $\begin{array}{c}\text { Proporsi pendapatan terhadap } \\
\text { penerimaan } \\
(\%)\end{array}$ \\
\hline 1 & $\mathrm{~N}$ & 54,68 & 45,32 \\
\hline 2 & $\mathrm{O}$ & 60,01 & 39,99 \\
\hline \multirow[t]{2}{*}{3} & $P$ & 57,57 & 42,43 \\
\hline & Rerata & 57,42 & 42,58 \\
\hline
\end{tabular}

Tabel 10, 11, dan 12 memperlihatkan bahwa rata-rata proporsi biaya produksi terhadap penerimaan sebesar berkisar antara $57,42 \%-81,16 \%$, lebih tinggi jika dibandingkan rata-rata proporsi pendapatan terhadap penerimaan yang berkisar antara $18,84 \%-42,58 \%$. Untuk menguji perbedaan antara setiap proporsi pada tingkatan luas lahan maka dilakukan uji t 2 sampel independen dengan rumus :

$$
\mathrm{t}=\frac{\overline{\mathrm{x}}_{1}-\overline{\mathrm{x}}_{2}}{\sqrt{\frac{\left(\mathrm{n}_{1}-\mathrm{n}_{2}\right) \mathrm{s}_{1}{ }^{2}+\left(\mathrm{n}_{2}-1\right) \mathrm{s}_{2}^{2}}{\mathrm{n}_{1}+\mathrm{n}_{2}-2}\left(\frac{1}{\mathrm{n}_{1}}+\frac{1}{\mathrm{n}_{2}}\right)}}
$$

(Hakim, 2007).

Hasil analisis uji t ditunjukkan dalam tabel berikut ini.

\section{Tabel 13. Uji t 2 Sampel Independen untuk Proporsi Biaya Produksi dan Pendapatan terhadap Penerimaan pada Berbagai Luas Lahan}

\begin{tabular}{crr}
\hline $\begin{array}{c}\text { Luas lahan } \\
\text { (ha) }\end{array}$ & $\begin{array}{c}\text { Rata-rata proporsi biaya produksi } \\
\text { terhadap penerimaan } \\
(\%)\end{array}$ & $\begin{array}{c}\text { Rata-rata proporsi pendapatan terhadap } \\
\text { penerimaan } \\
(\%)\end{array}$ \\
\hline$<0,5$ & $81,16^{\mathrm{a}}$ & $18,84^{\mathrm{a}}$ \\
$0,5-1$ & $65,13^{\mathrm{b}}$ & $34,87^{\mathrm{b}}$ \\
$>1$ & $57,42^{\mathrm{c}}$ & $42,58^{\mathrm{c}}$ \\
\hline Keterangan : Angka-angka yang diikuti oleh huruf yang sama tidak berbeda nyata pada $\alpha=5 \%$
\end{tabular}

Analisis uji t memperlihatkan perbedaan nyata proporsi biaya produksi dan pendapatan terhadap penerimaan pada berbagai luas lahan, di mana rata-rata tertinggi dari proporsi biaya produksi dan pendapatan terhadap penerimaan diperoleh pada usahatani dengan luas lahan 0,5 - 1 ha yang berbeda nyata dengan kedua luas lahan lainnya. Nilai tertinggi dari proporsi biaya produksi terhadap penerimaan diperoleh pada usahatani dengan luas lahan $<0,5$ ha, sedangkan nilai terendah dari proporsi pendapatan terhadap penerimaan juga diperoleh pada usahatani dengan luas lahan $<0,5$ ha. 
Perhitungan tersebut mengindikasikan adanya inefisiensi biaya produksi dalam usahatani padi sawah di Desa Toinasa, terutama pada petani yang mengusahakan areal lahan yang relatif kecil $(<0,5 \mathrm{ha})$. Artinya ialah semakin kecil luasan penanaman padi sawah, semakin tinggi inefisiensi biaya produksi usahatani, dan semakin kecil pendapatan yang diperoleh petani dari usahataninya.

Petani pada umumnya mengeluhkan tingginya harga sarana produksi berupa pupuk dan pestisida, apalagi jika sarana produksi tersebut mengalami kelangkaan atau tidak tersedia di pasaran. Biaya-biaya berupa pembajakan tanah dengan traktor dan sewa huller serta penggilingan juga mengalami peningkatan dari waktu ke waktu. Demikian pula ketersediaan modal usahatani yang diperlukan, terutama untuk memulaikan kembali operasi usahatani pada musim tanam selanjutnya. Hal-hal demikian seharusnya mendapat perhatian dari pihak pemerintah, secara khusus pemerintah daerah untuk memberi perhatian terhadap ketersediaan sarana produksi yang dibutuhkan petani melalui kebijakan pendistribusian sarana produksi tepat waktu dan atau pemberian subsidi bagi petani dalam hal perolehan sarana produksi dengan harga yang lebih murah.

Penguatan kelembagaan dan peningkatan akses petani terhadap kelembagaan juga merupakan syarat pokok yang diperlukan untuk mengatasi permasalahan yang dihadapi usahatani. Kelembagaan yang dimaksud ialah koperasi tani (koptan) untuk pembelian sarana produksi berupa benih, pupuk, pestisida dengan harga terjangkau dan penjualan hasil dengan harga yang menguntungkan, layanan penyuluhan untuk penerapan teknologi baru, dan lembaga perkreditan sebagai sarana memperoleh modal usahatani (Hanafie, 2010).

Pembentukan dan pengaktifan kelompok tani juga dapat dilakukan untuk memecahkan permasalahan yang tidak dapat diselesaikan oleh petani secara individu. Pembentukan kelompok tani merupakan proses perwujudan pertanian yang terkonsolidasi sehingga dapat berproduksi secara optimal dan efisien. Pengadaan sarana produksi dan penjualan dapat dilakukan secara bersama. Dengan demikian volume sarana produksi yang dibeli dan volume hasil yang dijual menjadi lebih besar, biaya pengadaan per satuan sarana produksi dan pemasaran per satuan hasil menjadi lebih rendah, dan peningkatan efisiensi usahatani dapat dicapai (Nuryanti dan Swastika, 2011).

\section{KESIMPULAN}

Luas lahan berpengaruh secara positif dan signifikan terhadap penerimaan, biaya produksi, dan pendapatan petani padi sawah di Desa Toinasa. Peningkatan luas lahan menyebabkan peningkatan penerimaan, biaya produksi, dan pendapatan. Akan tetapi, proporsi biaya produksi terhadap penerimaan lebih besar dibandingkan proporsi pendapatan terhadap penerimaan, sehingga terjadi inefisiensi biaya produksi usahatani. Diperlukan peran pemerintah untuk penyediaan berbagai sarana produksi melalui penguatan kelembagaan serta pembentukan dan pengaktifan kegiatan-kegiatan kelompok tani guna mengatasi berbagai permasalahan yang dihadapi oleh petani.

\section{REFERENSI}

Dewi, I.G.A.C., I.K.Suamba, dan I.G.A.A. Ambarawati, 2012. Analisis Efisiensi Usahatani Padi Sawah (Studi Kasus di Subak Pacung Babakan, Kecamatan Mengwi, Kabupaten Badung). Jurnal Agribisnis dan Agrowisata. 1 (1) : 1 - 10.

Hakim, A., 2007. Statistik Induktif untuk Ekonomi dan Bisnis. Penerbit Ekonisia. Yogyakarta.

Hanafie, R., 2010. Pengantar Ekonomi Pertanian. Penerbit Andi. Yogyakarta.

Isyanto, A.Y., 2012. Faktor-faktor yang Berpengaruh Terhadap Produksi pada Usahatani Padi di Kabupaten Ciamis. Jurnal Cakrawala Galuh. 1 (8) : 1 - 7 .

Kusnadi, N., N.Tinaprilla, S.H.Susilowati, dan A.Purwoto. Analisis Efisiensi Usahatani Padi di Beberapa Sentra Produksi Padi di Indonesia. Jurnal Agro Ekonomi. 29 (1) : $25-48$.

Mahananto, S.Sutrisno, dan C.F.Ananda, 2009. Faktor-faktor yang Mempengaruhi 
Produksi Padi (Studi Kasus di Kecamatan Nogosari, Boyolali, Jawa Tengah). Jurnal Wacana. 12 (1) : 179 - 191.

Nazam, M., S.Sabiham, B.Pramudya, Widiatmaka, dan I.W. Rusastra, 2011. Penetapan Luas Lahan Optimum Usahatani Padi Sawah Mendukung Kemandirian Pangan Berkelanjutan di Nusa Tenggara Barat. Jurnal Agro Ekonomi. 29 (2) : 113 -145 .

Nuryanti, S. dan D.K.S. Swastika, 2011. Peran Kelompok Tani dalam Penerapan Teknologi Pertanian. Jurnal Forum Penelitian Agro Ekonomi. 29 (2) : 115 128.

Prayoga, A., 2010. Produktivitas dan Efisiensi Teknis Usahatani Padi Organik Lahan Sawah. Jurnal Agro Ekonomi. 28 (1) : 1 19.

Ramadhani, Y., 2011. Analisis Efisiensi, Skala dan Elastisitas Produksi dengan Pendekatan Cobb-Douglas dan Regresi Berganda. Jurnal Teknologi. 4 (1) : 61 68.

Sudaryanto, T., S.H.Susilowati, dan Sumaryanto, 2009. Increasing Trend of Small Farms in Indonesia : Causes and Consequences. Paper presented at 111th EAAE - IAAE Seminar "Small Farms : Persistance or Declined ?" 25-26 June 2009, University of Canterbury, UK.

Somantri, A. dan S.A. Muhidin, 2006. Aplikasi Statistika dalam Penelitian. Pustaka Setia. Bandung.

Suratiyah, K., 2008. Ilmu Usahatani. Penebar Swadaya. Jakarta.

Susilowati, S.H. dan M.Maulana, 2012. Luas Lahan Usahatani dan Kesejahteraan Petani : Eksistensi Petani Gurem dan Urgensi Kebijakan Reforma Agraria. Jurnal Analisis Kebijakan Pertanian. 10 (1) : $17-30$. 
Jurnal Envira Volume 1 Nomor 2 Desember 2016 